ZOOLOGIA 30 (6): 601-606, December, 2013

http://dx.doi.org/10.1590/S1984-46702013005000006

\title{
Gender-related diet composition and morphometry of the Restinga Antwren, Formicivora littoralis (Aves: Thamnophilidae)
}

\author{
Flávia G. Chaves ${ }^{1} \&$ Maria Alice S. Alves ${ }^{2}$ \\ 1 Programa de Pós-graduação em Ecologia e Evolução, Universidade do Estado do Rio de Janeiro. Rua São Francisco Xavier 524, \\ 20550-011 Rio de Janeiro, RJ, Brazil. \\ 2 Departamento de Ecologia, Instituto de Biologia Roberto Alcantara Gomes, Universidade do Estado do Rio de Janeiro. \\ Rua São Francisco Xavier 524, 20550-011 Rio de Janeiro, RJ, Brazil. E-mail: masaal@globo.com
}

\begin{abstract}
Formicivora littoralis (Gonzaga and Pacheco, 1990), the Restinga Antwren, considered the only endemic bird species of the Restinga ecosystem (sandy plain coastal vegetation), is threatened with extinction. The scientific literature provides little information on the biology of this bird, which was discovered in 1990. We evaluate gender-related differences in the composition of the diet and morphometric measurements of this species. We tested the hypothesis that the sexes differ in what they eat and in morphometric characters. Our results revealed that the diet of the Restinga Antwren includes mainly arthropods, which is consistent with the diets of other Thamnophilidae. The lack of differences in the composition of the diet between the sexes does not support the hypothesis that habitat partitioning to avoid intraspecific competition is taking place. We found significant differences in six morphometric measurements, two in the beak and four in body size. It is possible that intraspecific differences between the sexes are a result of sexual selection, a hypothesis that needs to be tested.
\end{abstract}

KEY WORDS. Arthropods; food items; intraspecific variation; morphometry; restinga ecosystem.

Individuals of the same species differ from one another and may utilize different resources within a similar habitat (Bolnick et al. 2003). Differences may occur in response to ecological pressures such as risk of predation, competition for mates, quality of the territory and scarcity of resources. These differences among individuals have been ignored by a wide range of studies that considered them to be rare, weak or as being of little consequence to ecological processes (for examples, see Pielou 1972, Linton et al. 1981, Lomnicki 1988, DeAngelis \& Gross 1992). A theory about sexual dimorphism predicts that dimorphism in size (SDS) may result in different nutritional requirements between the sexes (SHELDon et al. 1998), which may be reflected in differences in their morphometric traits (SzéKeLY et al. 2007).

Morphometric studies quantify how shape and size influence individuals by affecting the items they are able to eat, their ability to compete, the selective pressure they are under, and the microhabitats they use (Peres-Neto 1995). Differences in the exploitation of ecological niches between the sexes may be better understood with the help of morphometric analyses combined with natural history studies, for instance diet composition and descriptions of mating systems (WinKLER \& LeISLER 1985, WeBSTER 1997). Intraspecific differences in foraging have been documented for woodpeckers (Order: Piciformes) (SELANDER 1966, Williams 1980) and flycatchers (Passeriformes) (Bell 1982), and can be generally explained in two ways: First, they may be the result of intraspecific resource partitioning (SELANDER 1966), and will be reflected in variations in beak proportions associated with differences in diet composition. A second cause of intraspecific differences in foraging are gender-specific and are associated with activities that happen only during the breeding season (Holmes 1986). In order to evaluate gender-specific foraging differences, it is necessary to determine and compare diet composition and morphometry between the sexes, and it was the approach taken in this study.

Three methods are commonly used to determine the composition of the diet of birds: 1) observations on foragingbehavior followed by recordings of captured items; 2) stool sample analysis; and 3) stomach content analysis through the induction of chemical emetic substances. The first method is sometimes inefficient because small food items are difficult to observe and record (REMSEN \& Robinson 1990). The second method allows for an easier collection of samples and has the advantage of causing little disturbance to the birds (RALPH et al. 1985, Rosenberg \& COOper 1990). However, the principal disadvantage of this method is the highly fragmented state of the food items. These items can be difficult to identify and may require the use of specialized bibliography and assistance from specialists (entomologists). The third method, stomach content analysis, is considered the best method because fragment identification is easier, given that they are less digested than in stool samples (Poulin et al. 1994b, Mallet-Rodrigues et al. 
1997). Nonetheless, this method may accidentally kill the subjects, and the risks of dying are high for some species (ZACH \& Falls 1976, Rosenberg \& CoOper 1990).

With regards to morphometry, body mass is the most widely measure of body size in birds (SzÉKELY et al. 2007) and is often used to identify sexual dimorphism in animals (FaIrbaIRN 1997). Male birds are frequently larger than females (DARWIN 1874, SzÉKelY et al. 2007). Other morphometric measurements have also been shown to differ between the sexes (Selander 1972, Price 1984, Badyaev \& Martin 2000, Blondel et al. 2002).

We present data on the Restinga Antwren, Formicivora littoralis Gonzaga \& Pacheco, 1990, a passeriform. Species in this order may present sexual dimorphism in plumage. The Restinga Antwren belongs to a family composed of primarily insectivores (ZIMMER \& Isler 2003), and is considered the only endemic bird species of the Restinga ecosystem (sandy plain coastal vegetation) (Gonzaga \& PACheco 1990). It has a very small range between the municipalities of Maricá (Jaconé Beach) and Armação dos Búzios (Matтos et al. 2009) and adjacent islands (Comprida and Cabo Frio) (Gonzaga \& Pacheco 1990) in the state of Rio de Janeiro. Due to the extremely small and fragmented range of this bird, it is categorized as nationally Critically Endangered (MACHADO et al. 2008) and globally and regionally Endangered (IUCN 2013, Alves et al. 2000).

The aim of the present study was to test the hypothesis that males and females of $F$. littoralis differ in the diets they eat and in some morphometric measurements. Gender-related differences in foraging had already been found in other passerines, and we had previously observed males of this species foraging in the vegetation above the females, which usually feed near the ground.

\section{MATERIAL AND METHODS}

This study was conducted in a Restinga fragment with an area of 13 hectares in Costa do Sol State Park, Araruama $\left(22^{\circ} 56^{\prime} 21.9^{\prime \prime} \mathrm{S}, 42^{\circ} 17^{\prime} 58.0^{\prime \prime} \mathrm{W}\right)$, state of Rio de Janeiro. The restinga is sandy plain coastal vegetation covered by a mosaic of plant communities that include many Atlantic forest species that have various adaptations to a drier habitat (DuARTe et al. 2005). The vegetation in the study area is characterized by dense, scrubby thickets (Araújo et al. 2009, Zimmer \& IsLer 2003), which comprise a "Low ridge thicket formation". Bromeliads and cacti are abundant (Gonzaga \& PACHeCO 1990), and some of the most common plant species in this formation are Schinus terebinthifolius Raddi, Zollernia glabra (Spreng.) Yakovlev, and Sideroxylon obtusifolium (Humb.ex Roem. \& Schult.) (Araújo et al. 2009). The scrub and tree plant species usually have thorns and form an impenetrable canopy that prevents light from penetrating (ARAújo et al. 2009). Leguminosae is the family with the greatest number of species in this area, followed by Cactaceae A.S.C. Cavalcanti (pers. comm.).

From December 2007 to October 2009, on a monthly basis, we captured individuals of $F$. littoralis for two consecutive days.
We used playback and six mist nets ( $12 \times 2.5 \mathrm{~m}, 36 \mathrm{~mm}$ mesh) for sampling. Mist nets remained open from 6:00 a.m. to 10:00 a.m. and from 3:00 p.m. to 6:00 p.m. Once a specimen was captured, we determined its sex by using the coloration of the plumage, and banded it with a metal ring and a unique pair of colored bands. After banding, each specimen was weighed with a Pesola ${ }^{\circledR}$ dynamometer (precision $0.5 \mathrm{~g}$ ) and measured with a ruler (precision $1 \mathrm{~mm}$ ) and caliper (precision $0.1 \mathrm{~mm}$ ). The following measurements were obtained: biomass, total length, wing length, tail length, exposed culmen, nostril-tip, beak height at the nostril and in the base, beak width in the nostril and in the base, tarsus length, and length of the head to the beak tip (SICK 1997).

After this procedure, birds were kept in clean-cotton bags for about 15 minutes in order for us to collect stool samples. Samples from the cotton bags were stored in ethanol (70\%) and analyzed in the laboratory with a stereoscopic microscope (Olympus SZX9). The Rio de Janeiro National Museum donated the stomach of a male bird from Cabo Frio, and this was analyzed together with the stool samples collected from other individuals from the study area.

Food items found in stool samples and stomach were identified to the level of order using scientific guides provided by several authors (CALVER \& Wooler 1982, Ralph et al. 1985, Chapman \& Rosenberg 1991, Racca-Filho et al. 2003, Manhães et al. 2010) and the assistance of specialists (J.R.M. Mermudes and I. Mattos). Immature life stages were grouped in the food category "Larvae" and ants were separated from the Hymenoptera food category and classified in the Formicidae food category. We included this separation for two reasons: 1) Formicidae differs from the rest of the Hymenoptera in morphometric and behavioral characteristics, and 2) this separation allowed us to compare our results with those from others studies (Delarmelina \& Alves 2009, Manhães et al. 2010). Hereinafter, Hymenoptera excludes Formicidae in the analysis. The number of individuals in each food category and in each sample analyzed was quantified following Calver \& Wooler (1982). For example, symmetrical anatomical items (such as wings, legs, elytra, and antennae) were counted in pairs.

To complement the data collected through stool samples, we obtained observational data from monthly transects established across the study grid, during the same period. These transects were sampled for the duration of one day from 6:00 a.m. to 9:00 a.m. We used Nikon binoculars $(8 \times 42)$ to identify the captured prey whenever possible. Cases when it was possible to identify the prey captured included larger prey items such as Orthoptera, Coleoptera and Lepidoptera, because the birds spend some time handling these prey items. This handling behavior was noted in this species by ZIMMER \& ISLER (2003). Restinga Antwrens are relatively fearless and usually forage near the observer, which enables occasional identification of the category of prey items captured.

We calculated the relative frequency of occurrence of each type of food category based on the number of feeding observa- 
tions with identified prey type and the minimum number of individuals identified in each stool sample. The sum of the relative frequencies of all prey types may exceed $100 \%$ because of the different food items found in each stool sample. Intraspecific comparison of prey consumption was performed using a Chi-square test and contingency table. Morphometric differences between sexes were compared by a Student $t$ test and principal components analysis (PCA). Statistical analyses followed ZAR (1984) and were carried out on the program Statistica, version 10 (STATSOFT 2011).

\section{RESULTS}

We captured 81 adults of $F$. littoralis (40 males and $41 \mathrm{fe}$ males), but only 58 stool samples ( 28 from males and 30 from females) were obtained. We did not collect more than one sample from the same individual. During transects, we identified 17 prey items ( 10 from males and 7 from females), of which beetles ( $n=5$, Coleoptera) and grasshoppers ( $n=7$, Orthoptera) were the most frequent. Most food items found in the diet of the Restinga Antwren were arthropods, which were identified by their mandibles, tibiae, claws, and heads in the stool samples.

Comparing intraspecific prey consumption, the food categories that were most frequently found in stool samples, stomach and observations were Coleoptera (37\% for males and $38 \%$ for females) and Formicidae (28\% and 30\% for males and females, respectively). Fragments of vegetable material (leaf), Hymenoptera, and Hemiptera were found only once in stool samples from females (Fig. 1). Since these items were not representative of the diet, these categories were excluded from the quantitative analysis. We did not find fruits or seeds in the samples analyzed. There was no significant difference between the sexes in the proportion of arthropods consumed (Chisquared; $\chi^{2}=2.3, \chi_{t}^{2}=16.9$, g.l. $=9$ ).

The average values of morphometric measurements $(\mathrm{mm})$ and biomass ( $\mathrm{g}$ ) of males and females were relatively similar (slightly greater values were found for males, but inconsistently so) (Table I). Six of the morphometric variables analyzed differed significantly between the sexes: total length, wing length, tail length, nostril-tip, beak height at the nostril, and length of the head to the tip of the beak. Despite the dependence between the variables wing and tail length with total length (body size), this did not influence the results, as these variables (wing and tail length) showed significant results, when the influence of the body size was removed (ANCOVA - wing length, $\mathrm{r}: 0.53 \mathrm{p}$ $=0.008$; length of tail, $\mathrm{r}: 0.33 \mathrm{p}=0.031)$. When we applied the Principal Component Analysis (PCA) technique with all variables together, the sexes were not separated (Fig. 2). The first two axes explained $40 \%$ of the variation found (axis $1-26.9 \%$ and axis $2-12.9 \%$ ). The variables that most contributed to the variation found in the first axis were total length (0.84) and right wing (0.72), while beak width at the nostril (0.64) and nostril-tip (0.63) associated more with the second axis.

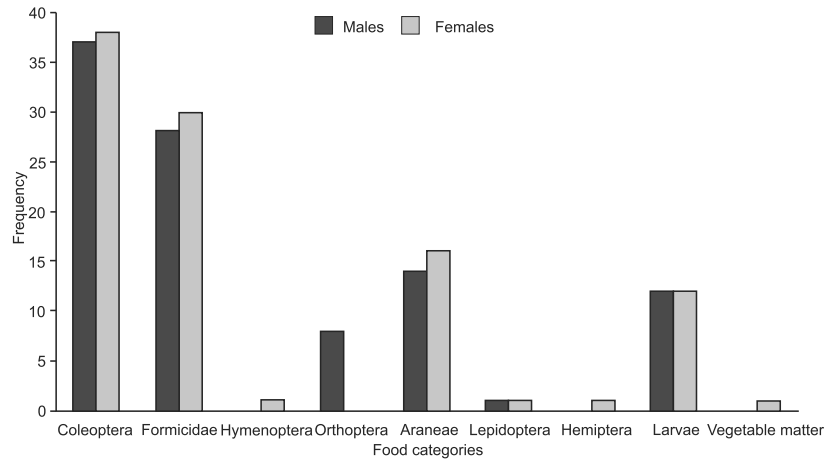

Figure 1. Comparison between sexes of frequency (\%) of food categories recorded by stool samples (male $=28$, females $=30$ ), stomach $($ male $=1)$ and direct observations (male $=67$, females $=68)$.

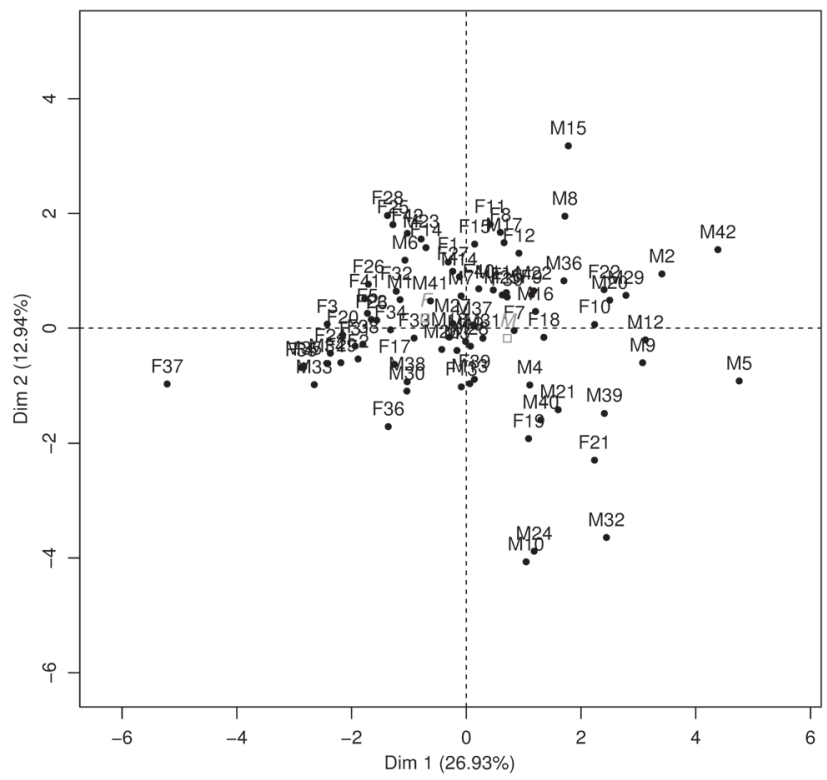

Figure 2. Principal Component Analysis (PCA) between Restinga Antwren sexes with all morphometric measurements.

\section{DISCUSSION}

Males and females of $F$. littoralis did not differ in the composition of their diets, but they did differ in some morphometric variables, including beak measurements. The diet of the Restinga Antwren was composed mainly by arthropods, which is in agreement with findings for other species of the family Thamnophilidae (SICK 1997, Zimmer \& IsLer 2003).

When we compared the diet of $F$. littoralis with the diets of species of the same genus, we observed differences in the frequencies (distribution of food items) or food categories. While F. littoralis consumed mainly insects in the food catego- 
Table I. Mean (x), standard deviation (sd), t-test result, and corresponding probabilities of morphometric measurements $(\mathrm{mm})$ and biomass $(\mathrm{g})$ of Formicivora littoralis males and females.

\begin{tabular}{lccc}
\hline Measurements $(\mathrm{mm})$ & $\begin{array}{c}\text { Males } \\
(\mathrm{x} \pm \mathrm{sd})\end{array}$ & $\begin{array}{c}\text { Females } \\
(\mathrm{x} \pm \mathrm{sd})\end{array}$ & $\mathrm{t}$-test; probability $(\mathrm{p})$ \\
\hline Biomass & $13.9 \pm 0.72$ & $13.0 \pm 0.84$ & $\mathrm{t}=0.86 ; \mathrm{p}=0.39$ \\
Total length & $122.7 \pm 3.52$ & $119.0 \pm 3.5$ & $\mathrm{t}=3.75 ; \mathrm{p}=0.0003^{*}$ \\
Wing length & $58.2 \pm 1.99$ & $56 \pm 2.19$ & $\mathrm{t}=4.74 ; \mathrm{p}=0.0001^{*}$ \\
Length of tail & $55.0 \pm 3.53$ & $52.3 \pm 2.32$ & $\mathrm{t}=2.03 ; \mathrm{p}=0.04^{*}$ \\
Tarsus length & $21.9 \pm 0.73$ & $21.8 \pm 0.67$ & $\mathrm{t}=0.28 ; \mathrm{p}=0.77$ \\
Exposed culmen & $14.7 \pm 1.05$ & $14.7 \pm 0.62$ & $\mathrm{t}=0.01 ; \mathrm{p}=0.98$ \\
Nostril-tip & $9.7 \pm 0.56$ & $9.5 \pm 0.49$ & $\mathrm{t}=2.11 ; \mathrm{p}=0.03^{*}$ \\
Beak height in nostril & $3.6 \pm 0.26$ & $3.5 \pm 0.19$ & $\mathrm{t}=2.37 ; \mathrm{p}=0.01^{*}$ \\
Beak width in nostril & $3.8 \pm 0.35$ & $3.7 \pm 0.21$ & $\mathrm{t}=1.42 ; \mathrm{p}=0.15$ \\
Beak height in base & $5.0 \pm 0.51$ & $5.0 \pm 0.47$ & $\mathrm{t}=0.34 ; \mathrm{p}=0.73$ \\
Beak width in base & $8.3 \pm 0.57$ & $8.1 \pm 0.45$ & $\mathrm{t}=0.36 ; \mathrm{p}=0.71$ \\
Head to beak tip & $33.8 \pm 0.85$ & $33.4 \pm 0.78$ & $\mathrm{t}=2.19 ; \mathrm{p}=0.03^{*}$ \\
\hline $\mathrm{N}$ total & 40 & 41 & \\
\hline
\end{tabular}

* Significant differences $(p<0.05)$.

ries Coleoptera and Formicidae, adults of Formicivora erythronotos Hartlaub, 1852 (Thamnophilidae) consumed, in descending order of frequency, Larvae, Araneae, and Coleoptera (E. Mendonça pers. comm.). Silva (1988), in his study on Formicivora grisea Boddaert, 1783 (Thamnophilidae), failed to quantify the species' diet into food categories. The same is true for the study of Poulin et al. (1994a), with the exception that they found fruits in $2 \%$ of the 114 regurgitated food samples from $F$. grisea. The same authors, in a subsequent work comparing food categories between species and different types of vegetation, did not find any fruits in samples $(n=96)$ regurgitated from F. grisea (Poulin et al. 1994b) and concluded that fruit had been occasionally consumed. For $F$. littoralis, in terms of plant consumption, only one stool sample from an F.littoralis female had a small piece of leaf. This suggests that leaves are only occasionally consumed by this species. There have been a few notes published about the diet of Formicivora iheringi Hellmayr, 1909 (Thamnophilidae). The species consumed arthropods from the Orthoptera and Lepidoptera food categories, Larvae and probably Araneae (Zimmer \& Isler 2003). Formicivora melanogaster Pelzeln, 1868 (Thamnophilidae) also consumed arthropods in the following food categories: Orthoptera, Lepidoptera, Larvae, and Araneae (Zimmer \& IsLer 2003). An analysis of only one stomach sample from Formicivora rufa Wied, 1831 (Thamnophilidae), revealed that this species ate items in the Hemiptera and Coleoptera food categories (ZIMMER $\&$ IsLer 2003). There is no information about the diet of Formicivora serrana Hellmayr, 1929 (Thamnophilidae).

There were large numbers of fragments of Coleoptera in stool samples from both sexes of the Restinga Antwren. The high frequency of Coleoptera and/or Formicidae in bird stool samples had also been reported in other studies with passerines (Poulin et al. 1994a, b, Mallet-Rodrigues 2001, Durães \& Marini 2005, Lopes et al. 2005, Manhães \& Dias 2008, Manhães et al. 2010). These two food categories are abundant in tropical forests, and occur in different vertical strata of the vegetation (Poulin \& Lefebvre 1997, Durães \& Marini 2005).

Differences in species or size of prey items consumed by adults of the same species may occur due to competition for resources or different nutritional requirements and consequently a partitioning of foraging areas is expected to occur (Ainley \& Boekelheide 1990, Sheldon et al. 1998). We did not find significant differences between the sexes in the proportion of arthropods consumed, although three different food categories - Vegetable material (leaf), Hymenoptera, and Hemiptera - which were only consumed by females, were excluded from the analysis because they only occurred once. We did not measure the prey items consumed because the arthropod fragments were highly digested. Thus, our results did not confirm a foraging partitioning between sexes.

Although we were not able to find differences in diet between the sexes, morphometric data showed that males are significantly larger than females in all measurements. HoLmes (1986) described two factors that possibly account for morphological differences between males and females. The first is related to habitat partitioning, which reduces intraspecific competition (Holmes 1986, Hedrick \& Temeles 1989). Selander (1966) added that, as a result of intraspecific competition for resources, some traits may vary between males and females, for instance bill sizes, which may result in differences in diet. Significant gender differences in morphometric traits (i.e., bill and tongue) and foraging behavior were found for Centurus woodpeckers (Selander 1966). For the Restinga Antwren, statistically significant differences were found between the sexes in two morphometric measurements of the bill (nostril-tip and bill width at the nostril). However, we did not find differences between the sexes in the proportion of arthropods consumed. Given that we did not find differences in diet composition, the idea that habitat partitioning to avoid intraspecific competition is in place has not been corroborated. The second explanation proposed for gender related morphological differences, according to Holmes (1986), is that intraspecific differences in morphology and behavior are related to activities performed by each sex during the breeding season. In this case, males may have larger body measurements than females as a result of sexual selection (DARWin 1874, ANDERSSON 1982, ANDERSSON \& ANDERSSON 1994, WeBster 1997). In species with territorial behavior, males frequently are involved in territorial defense activities, such as acquisition of sufficient nesting locations and fighting to obtain sexual partners (EIKENAAR et al. 2009, PIPER et al. 2000). Therefore, according to HoLmes (1986), males would forage close to their vocalization perches and females near their nests. The great majority of Thamnophilidae species are territorial (ZIMMER $\&$ IsLER 2003), and F. littoralis is not an exception. Sexual size 
dimorphism associated with different reproductive roles has been described in some studies (Greenwood \& Adams 1987, Mealy 2000, BlancKenhorn 2005). These authors argue that these differences correspond to traits that grant optimum fitness: males that become larger and stronger get more partners, whereas the size of females is regulated by optimum fecundity.

Our results on the diet of the Restinga Antwren, which is comprised mainly of arthropods, confirms other results obtained for Thamnophilidae. The lack of differences in diet composition between the sexes does not support the hypothesis that habitat partitioning to avoid intraspecific competition is taking place. It is possible that intraspecific differences in morphology between the sexes could be a result of sexual selection, a hypothesis that needs to be tested.

\section{ACKNOWLEDGEMENTS}

We thank members of the Laboratório de Ecologia de Aves (UERJ) for their help during fieldwork; José M. Mermudes and Ingrid Mattos for arthropod identification. We also thank Conservation International of Brazil for the fellowship granted to the first author (2008-2009), CNPq for fellowships currently granted (F.G.C. e M.A.S.A. - processes 148581/2010-2 and 308792/ 2009-2, respectively), and FAPERJ for the current grant (M.A.S.A. - process E-26/102.837/2012). CEMAVE/ICMBio for the license provided (number 15378). UERJ helped with logistical support and Boticário Foundation for Nature Protection provided financial support. Idea Wild donated part of the fieldwork equipment. Anonymous manuscript reviewers and the editor Walter Boeger contributed to improve the final version of this manuscript.

\section{LITERATURE CITED}

Ainley, D.G. \& R.Boekelheide. 1990. Seabirds of the Farallon Islands. Palo Alto, Stanford University Press.

Alves, M.A.S; J.F. Pacheco; L.A.P. Gonzaga; R.B. Cavalcanti; M.A. Raposo; C. Yamashita; N.C. Maciel \& M. Castanheira. 2000. Aves, p. 113-124. In: H.G. Bergallo; C.F.D. Rocha; M.A.S. Alves \& M. VAN SLUYS (Eds). A fauna ameaçada de extinção do Estado do Rio de Janeiro. Rio de Janeiro, Ed. UERJ, 166p.

Andersson, S. 1982. Female preferences for long tails in lekking Jackson's widowbirds: experimental evidence. Animal Behavior 43: 379-388. doi: 10.1016/S0003-3472(05)80098-3

Andersson, S. \& M. Andersson. 1994. Tail ornamentation, size dimorphism and wing length in the genus Euplectes (Ploceinae). The Auk 111: 80-86.

Araujo, D.S.D; C.F.C. Sá; J.F. Pereira; D.S. Garcia; M.V. Ferreira; R.J. Paixão; S.M. Schneider \& V.S. Fonseca-Kruel. 2009. Área de Proteção Ambiental da Massambaba, Rio de Janeiro: caracterização fitofisionômica e florística. Rodriguésia 60 (1): 54-84.

BaDyaev, A.V. \& T.E. Martin. 2000. Sexual dimorphism in relation to current selection in the house finch. Evolution 54 (3): 987 997. doi: 10.1554/0014-3820(2000)054[0987:SDIRTC]2.3.CO:2
BeLL, H.L. 1982. Sexual differences in the foraging behavior of the Frill-necked Flycatcher Arses telescopthalmus in New Guinea. Austral Journal of Ecology 7: 137-147.

BLANCKENHORN, W.U. 2005. Behavioral causes and consequences of sexual size dimorphism. Ethology 111: 977-1016.

Blondel, J.; P. Perret; M.C. Anstett \& C. Thébaud. 2002. Evolution of sexual size dimorphism in birds: test of hypotheses using blue tits in contrasted Mediterranean habitats. Journal of Evolution Biology 15: 440-450. doi: 10.1046/j.14209101.2002.00397.

BolNICK, D.I.; R. SVAnBÄCK; J.A. FordYCE; L.H. YanG; J.M. DavIS; C.D. HuLSEY \& M.L. Forister. 2003. The Ecology of Individuals: Incidence and Implications of Individual Specialization. The American Naturalist 161: 1-28. Doi: 0003-0147/2003/16101-010277.

Calver, M.C. \& R.D. Wooler. 1982. A technique for assessing the taxa, length, dry weight and energy content of the arthropod prey of birds. Australian Wildlife Research 9: 293-301. doi:10.1071/WR9820293.

Chapman, A. \& K.V. Rosenberg. 1991. Diets of four sympatric Amazonian woodcreepers (Dendrocolaptidae). The Condor 93: 904-915.

DARwin, C. 1874. The descent of man, and selection in relation to sex. Chicago, 528p.

DeAngelis, D.L. \& L.J. Gross. 1992. Individual-based models and approaches in Ecology. New York, Springer, 525p.

Delarmelina, A.F.P. \& M.A.S. Alves. 2009. Utilização de recursos alimentares por Philydor atricapillus e P. rufum (Aves: Furnariidae) em uma área de Mata Atlântica da Ilha Grande, RJ. Revista Brasileira de Ornitologia 17 (1): 59-64.

Duarte, H.M.; A. Gebler; F.R. Scarano; A.C. Franco; E.A. Mattos; M. Nahm; H. Rennenberg; P.J.F.P. Rodrigues; T. Zaluar \& U. LuTTGE. 2005. Ecophysiology of six selected shrub species in different plant communities at the periphery of the Atlantic Forest of SE-Brazil. Flora 200: 456-476. doi: 10.1016/ j.ûora.2005.02.004.

DurÃEs R. \& M.Â. MARINI. 2005. A quantitative assessment of Bird diet in the Brazilian Atlantic Forest, with recommendations for future diet studies. Ornitologia Neotropical 16: 65-83.

EikenaAr, C.; D.S. Richardson; L. Brouwer; R. Bristol \& J. Komdeur. 2009. Experimental evaluation in a cooperatively breeding bird. Behavioral Ecology 20: 207-214. doi: 10.1093/beheco/arn136

Fairbairn, D.J. 1997. Allometry for sexual size dimorphism: pattern and process in the coevolution of body size in males and females. Annual Review of Ecology and Systematics 28: 659-687. doi: 10.1146/annurev.ecolsys.28.1.659.

Gonzaga, L.P. \& J.F. PAcheco. 1990. Two new subspecies of Formicivora serrana (Hellmayr) from southeastern Brazil, and notes on the type locality of Formicivora deluzae Ménétriés. Bulletin of British Ornithology 110 (4): 187-193.

Greenwood, P.J. \& J. AdAms. 1987. Sexual selection, size dimorphism and a fallacy. Oikos 48: 106-108.

Hedrick, A.V. \& E.J. Temeles. 1989. The evolution of sexual dimorphism in animals: hypotheses and tests. Trends in Ecology and Evolution 4: 136-138. 
HoLmes, R.T. 1986. Foraging patterns of forest birds: male-female differences. Wilson Bulletin 98 (2): 196-213.

IUCN. 2013. IUCN Red List of Threatened species. Available online at: http://www.iucn.org [Accessed: 30/V/2013].

LinTON, L.R.; R.W. DAVIES \& F.J. Wrona. 1981. Resource utilization indices: an assessment. Journal of Animal Ecology 50: 283292.

Lomnick, A. 1988. Population Ecology of Individuals. Princeton, Princeton University Press, 223p.

Lopes, L.E.; A.M. Fernandes \& M.A. Marini. 2005. Diets of some Atlantic forest birds. Ararajuba 13 (1): 95-103.

Machado, A.B.M.; G.M. Drummond \& A.P. Paglia. 2008. Livro vermelho da fauna brasileira ameaçada de extinção. Belo Horizonte, Fundação Biodiversitas, 1420p.

Mallet-Rodrigues, F. 2001. Foraging and diet composition of the black-capped-foliage-gleaner (Philydor atricapillus). Ornitología Neotropical 12: 255-263.

Mallet-Rodrigues, F.; V.S. Alves \& M.L.M. Noronha. 1997. O uso do tártaro emético no estudo da alimentação de aves silvestres no estado do Rio de Janeiro. Ararajuba 5: 219-228.

Manhães, M.A. \& M.M. DiAs. 2008. Diet and feeding preference of the Plain Antvireo (Dysithamnus mentalis) in an area of Brazilian Atlantic forest. Ornitologia Neotropical 19 (3): 417-426.

Manhães, M.A.; A. Loures-Ribeiro \& M.M. Dias. 2010. Diet of understorey birds in two Atlantic Forest áreas of southeast Brazil. Journal of Natural History 44:7-8, 469-489. doi: 10.1080/00222930903380947.

Mattos, J.C.F.; M.M. Vale; M.B. Vecchi \& M.A.S. Alves. 2009. Abundance, distribution and conservation of the Restinga Antwren, Formicivora littoralis (Aves: Thamnophilidae). Bird Conservation International 1: 1-9. doi: 10.1017/S09592709 09008697.

Mealey, L. 2000. Sex diferences. Developmental and Evolutionary Strategies. San Diego, Academic Press, 480p.

Peres-Neto, P.R. 1995. Introdução às análises morfométricas, p. 5789. In: P.R. Peres-Neto (Ed.). Tópicos em Tratamento de Dados Biológicos. Rio de Janeiro, Universidade do Brasil, II+161p.

Pielou, E.C. 1972. Niche Width and Niche Overlap: a method for measuring them. Ecology 53: 687-692. doi: 10.2307/1934784

PiPER, W.H.; K.B. Tischler \& M. KLICH. 2000. Territorial acquisition in loons: the importance of take-over. Animal Behavior 59: 385-394. doi: 10.1006/anbe.1999.1295

Poulin, B. \& G. Lefebvre. 1997. Estimation of arthropods available to birds: effect of trapping technique, prey distribution and bird diet. Journal of Field Ornithology 68: 426-442.

Poulin, B.; G. Lefebvre \& R. McNeil. 1994a. Characteristics of feeding guilds and variation in diets of bird species of three adjacent tropical sites. Biotropica 26 (2): 187-197.

Poulin, B.; G. Lefebvre \& R. McNeil. 1994b. Diets of Land Birds from Northeastern Venezuela. The Condor 96: 354-367.

PrICE, T.D. 1984. The evolution of sexual size dimorphism in Darwin's finches. The American Naturalist 123: 500-518.
Racca-Filho, F.; A.F. Lima; M.S. Guarajá; I.L.R. Filho \& C.A.C. SAntos. 2003. Caderno Didático de Entomologia Geral Morfologia. Rio de Janeiro, Editora UFRRJ, I+95p.

Ralph, C.P.; S.E. Nagata. \& C.J. Ralph. 1985. Analysis of droppings to describe diets of small birds. Journal of Field Ornithology 56 (2): 165-174.

Remsen, J.V. \& S.K. Robinson. 1990. A classification scheme for foraging behavior of birds in terrestrial habitats. Studies in Avian Biology 13: 144-160.

Rosenberg, K.V. \& R.J. Cooper.1990. Approaches to avian diet analysis. Studies in Avian Biology 13: 80-90.

Selander, R.K. 1966. Sexual dimorphism and differential niche utilization in birds. The Condor 68: 113-151.

Selander, R.K 1972. Sexual selection and dimorphism in birds, p. 180-230. In: B. CAmpbell (Ed.). Sexual Selection and the Descent of Man 1871-1971. Chicago, Aldine, 378p.

Sheldon, B.C.; J. Merilä; G. Lindgren \& H. Ellegren. 1998. Gender and environmental sensitivity in nestling collared flycatchers. Ecology 79: 1939-1948.

SICK, H. 1997. Ornitologia brasileira. Rio de Janeiro, Editora Nova Fronteira, II+912p.

SiLVA, J.M.C. 1988. Aspectos da ecologia e comportamento de Formicivora g. grisea (Boddaert, 1989) (Aves: Formicariidae) em ambientes amazônicos. Revista Brasileira de Biologia 48 (4): 797-805.

Statsoft, Inc. 2011. Statistica. Data analysis software system, version 10. Available online at: http://www.statsoft.com [Accessed: 20/VII/2012].

Székely, T.; T. Lislevand \& J. Figuerola. 2007. Sexual size dimorphism in birds, p. 27-37. In: D.J. Fairbairn; W.U. BlanCKENHORN \& T. SzéKelY (Eds). Sex, size, and gender roles: evolutionary studies of sexual size dimorphism. Oxford, Oxford University Press, 266p.

Webster, S.M. 1997. Extreme sexual size dimorphism, sexual selection, and the foraging ecology of Montezuma oropendolas. The Auk 114 (4): 570-580.

WiLliams, J.B. 1980. Intersexual niche partitioning in Downy Woodpeckers. Wilson Bulletin 92: 439-451.

WINKLER, H. \& B. LEISLER. 1985. Mophological aspects of habitat selection in birds, p. 415-334. In: M.L. Cody (Ed.). Habitat selection in birds. San Diego, Academic Press, 558p.

ZACH, R. \& J.B. Falls. 1976. Bias and mortality in the use of tartar emetic to determine the diet of oven birds (Aves: Parulidae). Canadian Journal of Zoology 54: 1599-1603.

ZAR, J.H. 1984. Biostatistical analysis. New Jersey, PrenticeHall, 960p.

Zimmer K.J. \& M.L. Isler. 2003. Family Thamnophilidae (Typical antbirds). Barcelona, Lynx Edicons, VIII+ 845p.

Submitted: 13.IX.2012; Accepted: 14.VIII.2013.

Editorial responsibility: Kleber Del Claro 